island." It will be found, by turning over the Reports of the Brit. Assoo., the Trans. Roy. Geol. Soc. of Cornwall, and the "Geologist," that my "valuable data" have not been "long buried." Will Mr. Salter be so good as to say what is the evidence that "near Teignmouth we have the Upper Devonian beds?" I have no doubt that his reply will be that pebbles containing Clymenia are abundant in the Triassic Conglomerate at Shaldon, near Teignmouth, and that the Upper or Clymenia limestone must have existed close by. This, however, if admissible, would be evidence of not what is, but what was. But is it admissible? The Clymenize are found only in wellrounded pebbles, which have clearly travelled long-perhaps far; whilst the ordinary materials are but sub-angular, and are of immediate derivation. The Chesil beach at Portland contains, it is said, pebbles from the Torbay limestones. They must have travelled at least thirty-five miles, more likely double that distance, since, in all probability, they followed the sinuosities of the coast; a fact which suggests caution in drawing inferences from pebbles respecting the whereabouts of their parents.- I am, etc.

Wm. Pengeily.

ToRQuar, May 2, 1867.

\title{
FOSSIL INSECTS IN THE CARBONIFEROUS ROCKS.
}

\section{To the Editor of the Geologicau Magazine.}

Dear Sir,-I see in the March number of the Grologrcal MaGazine that you mention the occurrence of the "Xylobius Sigillaria?" in the Upper Coal Measures at Kilmaurs, in Scotland ; and in the same number Mr. Binney records the discovery of the same myriapod in the Lower Coal Measures near Huddersfield, and also the remains of a supposed Coleopterous insect. Now as the German and Belgian Carboniferous formations, especially the latter, and the American Coal fields have yielded in places numerous insects, and our own occasionally, I have very little doubt that a more careful search would largely increase the number; and I hope the many zealous collectors in our Coal-districts will keep a sharp look-out for any Annulosa which they may fairly expect to find associated with the plants in the shales and ironstones, especially in the latter, where they usually occur. The fine Curculionideous beetle in ironstone from Coalbroke Dale, and the scorpion from Cholme in Bohemia, long since figured and described by Buckland in the Bridgewater Treatise, are well known. There is also a fine wing of a "Corydalis", in the British Museum, from the same locality, figured and referred to in Murchison's "Siluria." I have in my collection a wing of a gigantic Neuropterous insect, in ironstone from the Derbyshire Coal Measures. Professor Dana, in the "American Journal of Science" (vol. xxxvii. January, 1864), describes and figures a remarkable fossil insect nearly entire, which he states to be like the Semblids among the Neuropters, and especially the Chauliodes, and a mutilated wing of another Neuropter, which approximates to the genus Hemerobius. Both these specimens were discovered by Mr. J. G. Bronson in the Carboniferous beds at Morris, Mlinois. Sir 
C. Iyell refers to the presence of wings of Blatta and Acridites in the coal in Westphalia, and to a still larger series of insect remains in the ironstone near Treves, among which are several Blattida, Neuroptera, Termites, one Scarabaus, and the wing of a large Gryllus which he figures under the name of "Gryllacris lithanthrace" (Manual of Geology, sixth edition). The presence of spiders and scorpions, and the state of preservation of the oldest known fossil spider from the coal in Upper Silesia, is worthy of note. This specimen is remarkably perfect, and is embedded in a white kind of shale, and the body stands ont in relief on the surface, showing the four pairs of legs, the two palpi, and even the coriaceous integument of the body (see Grou. Mag. 1865, Vol. II. p. 468).

I was glad to have an opportunity of examining this rare and interesting fossil when exhibited by the fortunate possessor, Professor Römer, at the meeting of the British Association in Birmingham, in 1865. Hitherto I have looked in vain for them in the series; but some day they will very likely be discovered, for we can hardly believe that such a number and variety of insects inhabited the land during the Liassic epoch, were not preyed upon by spiders and other creatures (Insectivorous mammals?) associated with them.

Vicarage, Rowingtan, WarWick,

P. B. Brodie. April 7 th, 1866.

DIPLOGRAPSUS TERETIUSCULUS IN THE UPPER LLANDOVERY OF HAVERFORDWEST.

To the Editor of the Geologicau Magazink.

Str,-A short time ago Mr. Lightbody and I, when on our way to St. David's to look at the old rocks there, availed ourselves of the opportunity of examining the two celebrated fossil localities near Haverfordwest, Sholes' Hook, and the Gas-works cutting.

In the latter we met with a fossil very much about the position which has hitherto been assigned it. The strata at the Gas-works have generally been regarded as Upper Llandovery; and in them we found the following fossils, - Nidulites favus, Petraia subduplicata var. crenulata, very abundant; Stenopora fibrosa, Tentaculites Anglicus, Orthis biforatus, O. calligramma, var. Walsalliensis, Strophomena antiquata, S. pecten, S. expansa, Leptena sericea, and Murchisonia gyrogonia. This is an association quite common. But along with these occurs Diplograpsus teretiusculus, a form hitherto unknown higher than the Upper Llandeilo ; and of which Mr. Salter says, " is a characteristic Llandeilo species never falling, as I believe, below or rising above that formation" (Appendix to Memoirs of Geol. Survey, vol. iii. page 330).

Double graptolites have also been met with in the Lake country, in the Coniston flags of Broughton Moor strata, which are probably near the horizon of those of the Haverfordwest Gas-works. I am not, however, aware that $D$. teretiuscullus has been found here; careful looking may very probably discover it.

Quenen's Colmege, Cork, Yours truly, RoBkRT HaRkness. 9 th May, 1867. 